\title{
Pemanfaatan Tren Artis Nyaleg Dalam Strategi Komunikasi Pemasaran Stand-Up Comedy 'Pragiwaksono World Tour'
}

\author{
Raka Radhitia Oktavianto ${ }^{1}$, Mukaromah ${ }^{2}$ \\ ${ }^{1}$ Universitas Dian Nuswantoro/Prodi Ilmu Komunikasi \\ Email : raka.radhitia@gmail.com ${ }^{1}$
}

\begin{abstract}
ABSTRAK
Inovasi adalah hal mutlak dalam mengkomunikasikan suatu barang maupun jasa. Komunikasi Pemasaran yang baik bukanlah sebuah kebetulan melainkan hasil dari perencanaan yang matang dan pelaksanaan yang cermat sebagai salah satu cara untuk meningkatkan kesadaran (awareness) akan keberadaan produk atau jasa ke khalayak yang dibidik. Hal itulah yang dilakukan oleh Pandji Pragiwaksono dalam memasarkan stand-up comedy special terbarunya yaitu Pragiwaksono World Tour. Dengan mengikuti perbincangan yang hangat di masyarakat tentang tahun politik, Pandji mengkomunikasikan event-nya dengan memasang baliho, iklan di media sosial dengan tema seolah-olah dirinya sebagai caleg (Calon Legislatif) untuk mendapat perhatian dari masyarakat. Penelitian ini bertujuan untuk mengetahui dan memberikan deskripsi mengenai pemanfaatan fenomena artis Nyaleg sebagai strategi komunikasi pemasaran pada Pertunjukan Stand-Up Comedy Special Pragiwaksono World Tour. Teori yang digunakan adalah Komunikasi Pemasaran dengan menggunakan metodologi penelitian deskriptif kualitatif. Hasilnya diperoleh dari 14 (empat belas) poin penetapan strategi komunikasi yang disampaikan oleh Cangara, dimulai dari pemilihan komunikator yang tepat, media yang di pilih, hingga yang paling akhir langkah evaluasi atas strategi komunikasi pemasaran apabila tidak berjalan sesuai yg diharapkan.
\end{abstract}

Kata Kunci: Artis Nyaleg, Pragiwaksono World Tour, Strategi Komunikasi

\section{Utilization of Nyaleg Artist Trends In Marketing Communication Strategies Stand-Up Comedy 'Pragiwaksono World Tour'}

\begin{abstract}
Innovation is an absolute thing in communicating an item or service. Good marketing communication is not a coincidence but is the result of careful planning and careful implementation as a way to increase awareness of the existence of products or services to the intended audience. That is what Pandji Pragiwaksono did in marketing his latest stand-up special comedy, Pragiwaksono World Tour. By following a heated conversation in the community about the political year, Pandji communicated his event by installing billboards, advertisements on social media with the theme as if he were a candidate (Legislative Candidate) to get the attention of the public. This study aims to determine and provide a description of the use of the Nyaleg artist phenomenon as a marketing communication strategy at the Pragiwaksono World Tour Stand-Up Comedy Special Show. The theory used is Marketing Communication using qualitative descriptive research methodology. The results are obtained from the implementation of the communication strategy determination points submitted by Cangara, starting from the selection of the right communicator, the media chosen, to the very last step of the evaluation of the marketing communication strategy if it does not go as expected.
\end{abstract}

Keywords: Artis Nyaleg, Pragiwaksono World Tour, Communication Strategy 
Korespondensi: Mukaromah M.I.Kom, Univeristas Dian Nuswantoro. Alamat Jl. Imam Bonjol 207 Semarang. No. HP; 085290736076 Email: mukaromah@dsn.dinus.ac.id

\section{PENDAHULUAN}

Suatu produk, jasa maupun event apabila dikomunikasikan dengan unik dan berbeda, besar kemungkinan akan dapat menarik perhatian khalayak. Dalam hal pemasaran, inovasi bisa dikatakan sebagai ide segar yang dapat meningkatkan nilai jual suatu produk. Inovasi yang berhasil akan menghasilkan berbagai keuntungan bagi pebisnis mulai dari meningkatnya penjualan produk, meningkatkan kesadaran masyarakat tentang brand kita hingga memiliki pelanggan yang selalu setia menunggu produk-produk terbaru. Pemasaran yang baik bukanlah sebuah kebetulan melainkan hasil dari perencanaan yang matang dan pelaksanaan yang cermat.Awal tahun 2018 lalu, tepatnya pada 14 Maret 2018 dalam situs resminya di pilihpandji.com, Pandji Pragiwaksono yang merupakan seorang artis stand up comedian mengumumkan untuk kembali membuat pertunjukan tur dunia terkait stand-up comedy special dengan tema Pragiwaksono World Tour. Dalam pertunjukan stand-up special tersebut panji menjanjikan akanbercerita tentang dirinya dan kehidupan masa lalu serta prosesnya dalam menjalani kehidupan. Dalam event pertunjukkannya tersebut Pandji akan membungkus kegiatan Pragiwaksono World Tour dengan isu-isu yang tengah hangat terjadi saat itu, termasuk yang berhubungan dengan dunia politik.

Pada peride tahun 2017-2019 adalah periode dimana banyak kegiatan politik di tanah air. Mulai dari pemilihan kepala daerah (pilkada), pilihan calon legislatif (caleg) hingga pemilihan presiden dan wakil presiden Indonesia. Jumlah artis nyaleg saat pemilu maupun pilkada mengalami peningkatan. Pada tahun 2014 dikutip dari portal Nasional Kompas, jumlah artis nyaleg saat pemilu maupun pilkada pada saat itu berada pada kisaran 60 orang

(https://nasional.kompas.com/read/2013/07/22/11

29342/Melongok.Artis.yang.Kembali.Nyaleg).

Sedangkan pada pemilu 2019 ini terdapat 91 calon legislatif yang berasal dari kalangan artis, meningkat lebih dari $50 \%$ dibanding dengan pemilu-sebelumnya.

(https://kumparan.com/@kumparannews/daftar91-caleg-artis-dpr-ri-di-pileg-2019).Tersebutlah beberapa nama yang mewakili fenomena artis yang terjun ke dunia politik khususnya dalam pemilihan calon legislative atau pemilukada seperti Pasha Ungu, Hengky Kurniawan, Aldy Fairus, Desy Ratnasari, Tina toon dll.

Berbekal kepekaannya terkait moment pertunjukkannya yang mendekati tahun tahun politik (2018-2019) maka Pandji Pragiwagsono berkenaan dengan pertunjukan stand up comedynya tersebut. Berbekal pengalamannya menjadi tim pemenangan Gubernur Anies Baswedan dan Sandiaga Uno di tahun 2017 an yang merupakan awal dikenalnya Pandji dalam dunia politik membuatnya semakin yakin untuk menggunakan isu politik dalam mempromosikan kegiatannya. Dimulai pada pemasangan billboard di kota Bandung, yang berisikan foto dirinya menggunakan batik laksana tokoh yang sedang 
mencalonkan diri dalam pilihan legislatif (Caleg)

dan beberapa rangkaian kegiatan lainnya.

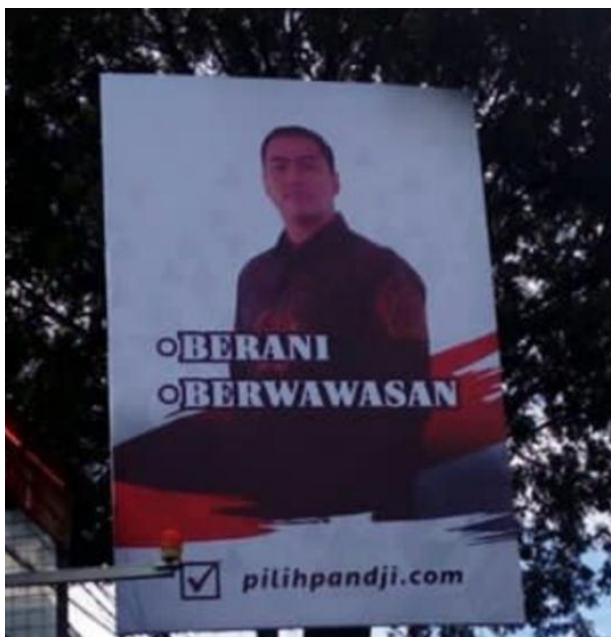

Gambar 1.1

Materi Promosi Stand Up Comedy Special Pragiwaksono World Tour Yang Menyerupai Pilihan Caleg (Sumber:

https://twitter.com/ainunnazarr/status/963959958848004096/pho to/1)

Pada awal melihat baliho ini, banyak warganet yang berspekulasi bahwa Pandji akan terjun ke dunia politik, seiring dengan pemberitaan tentangnya yang mendukung pencalonan Anies Baswedan -Sandiaga uno sewaktu pencalonan sebagai Gubernur dan Wakil Gubernur Jakarta.

Dengan memanfaatkan ueforio pemberitaan sebelumnya terkait dirinya, Pandji jeli memanfaatkan hal ini untuk memasarkan kegiatan stand-up comedy Pragiwaksono World Tour. Selain memalui baliho terlihat bahwa Pandji juga memanfaatkan media sosial seperti Twitter, Instagram, dank anal Youtube. Adanya berbagai bentuk promosi pemasaran kegiatan ini seolah terkesan bahwa Panji ingin kembali terjun ke dunia politik.

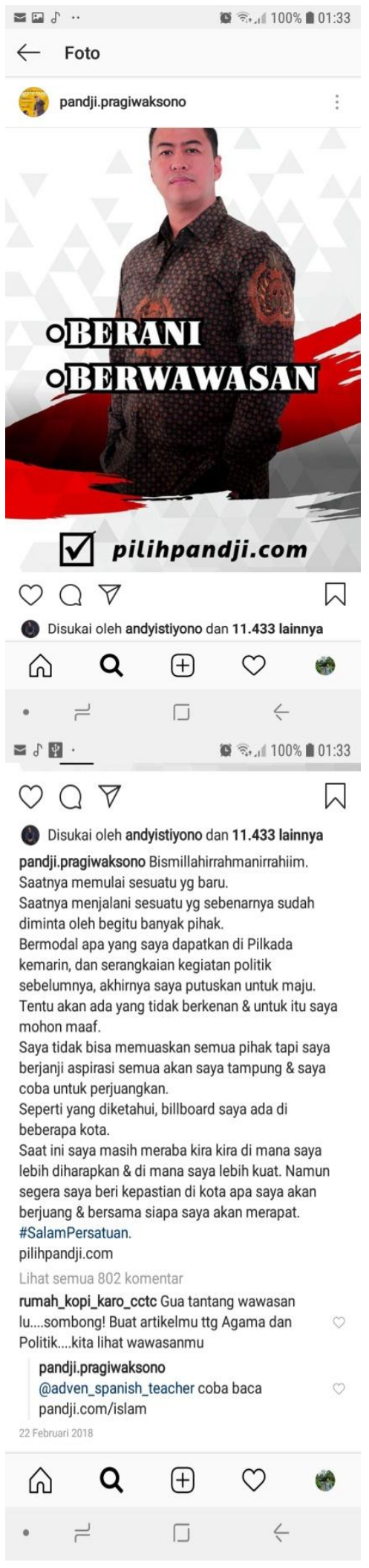

Gambar 1.2

Screenshoot unggahan pada akun Instagram Pandji Pragiwaksono

(Sumber : instagram.com/pandji.pragiwaksono) 


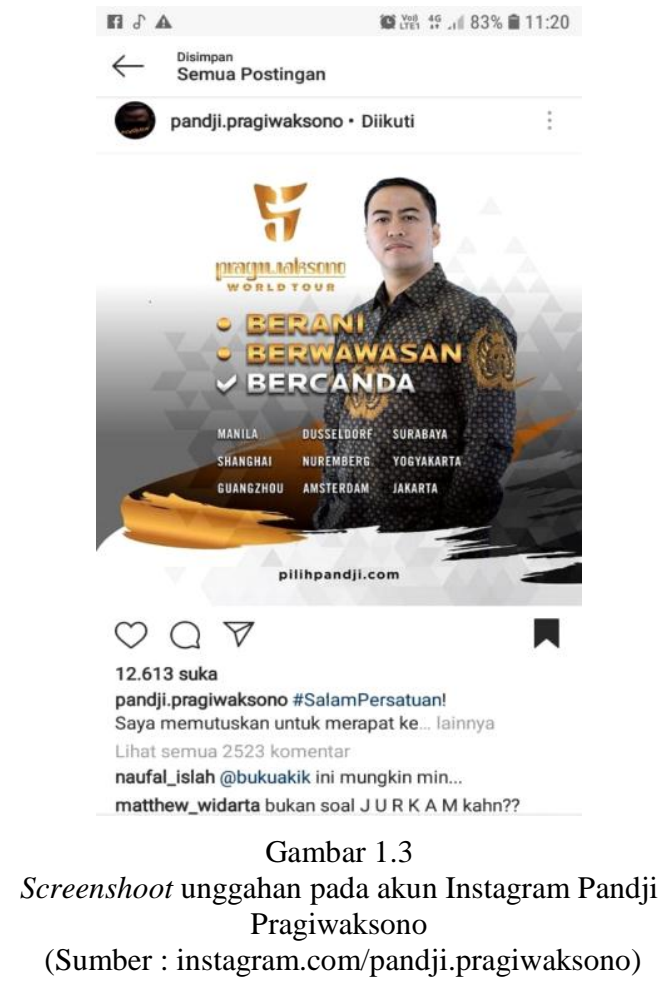

Pada data tersebut muncul beragam umpan balik oleh warganet yang menunjukan keterkejutan terhadap kampanye yang dilakukan Pandji selama ini. Hal ini menunjukan bahwa masyarakat menganggap iklan maupun unggahan yang disematkan oleh Pandji merupakan gambaran bahwa dirinya akan menjadi calon legislatif (caleg).

Tujuan yang ingin dicapai dengan adanya penelitian ini adalah untuk mengetahui dan memberikan deskripsi mengenai Pemanfaatan Fenomena Artis Nyaleg Sebagai Strategi Komunikasi Pemasaran pada Pertunjukan StandUp Comedy Special Pragiwaksono World Tour. Adapun teori yang digunakan dalam penelitian ini yaitu komunikasi di bidang pemasaran. Secara sederhana komunikasi pemasaran terdiri dari dua bidang keilmuan yaitu komunikasi dan pemasaran. Komunikasi menurut Houvland (dalam Effendy, 2006 : 10) adalah suatu proses mengubah perilaku orang lain (communication is the process to modify the bahavior of other individuals). Sedangkan pemasaran menurut Kotler \& Armstrong (2012 : 5) adalah sebuah proses yang dilakukan perusahaan untuk membuat suatu nilai dan membangun hubungan baik dengan konsumen guna menangkap nilai yang lebih dari konsumen. Menurut Effendy (2006 : 35), strategi adalah sebuah perencanaan atau planning dan manajemen yang dilakukan untuk mencapai suatu tujuan yang hanya dapat diraih dengan taktik operasional.Strategi komunikasi hendaknya mencakup segala kebutuhan untuk mengetahui bagaimana cara berkomunikasi dengan sasaran. Untuk mencapai tujuan tersebut strategi komunikasi diharapkan dapat mendefinisikan taktik operasionalnya dalam arti bahwa pendekatan (approach) komunikator terhadap komunikan akan selalu berbeda sewaktu-waktu sesuai situasi dan kondisi.

Penetapan strategi dalam perencanaan komunikasi akan kembali kepada elemen komunikasi, seperti yang terdapat dalam buku Perencanaan \& Strategi Komunikasi karya Hafied Cangara (2013 : 133) bahwa strategi komunikasi akan dijalankan dalam perencanaan komunikasi yang diawali dengan langkah-langkah seperti (1) Memilih dan Menetapkan Komunikator,(2) Menetapkan Target Sasaran dan Analisis Kebutuhan Khalayak.(3) Teknik Menyusun Pesan, (4) Memilih Media atau Saluran Komunikasi,(5) Telepon Selular dan SMS, (6) Produksi Media, (7) Uji Awal Materi Komunikasi, (8)Penyebarluasan Media Komunikasi, (9)Menganalisis Efek 
Komunikasi,(10) Memobilisasi Kelompok

Berpengaruh, (11) Penetapan Rencana Anggaran, (12) Penyusunan Jadwal Kegiatan, (13) Penetapan Tim Kerja dan (14) Evaluasi dan Audit Komunikasi

\section{METODE PENELITIAN}

Pendekatan penelitian kualitatif, dengan pendekatan studi kasus, obyek penelitiannya adalah pemanfaatan fenomena artis nyaleg dalam strategi komunikasi pemasaran Stand-Up Comedy Special Pragiwaksono World Tour. Dengan data primer yaitu yaitu pihak penyelenggara Stand-Up Comedy Special Pragiwaksono World Tour. Manager dan Pandji Pragiwaksono sendiri. Data sekunder berasal dari buku-buku dan kajian penunjang. Teknik pengumpulan data dengan wawancara mendalam dan observasi lapangan secara langsung. Proses analisis data dilakukan dengan menggunakan tahapan reduksi data, pengajian data dan penyimpulan data. Penarikan kesimpulan penelitian ini dengan analisis triangulasi.

\section{HASIL DAN PEMBAHASAN}

Pada tahun 2018 lalu, munculnya billboard yang berisikan pesan yang seakan-akan menyampaikan bahwa Pandji Pragiwaksono akan terjun ke dunia politik dengan mencalonkan diri sebagai calon legislatif (caleg). Kegiatan ini ternyata salah satu upaya strategi pemsaran kegiatan pertunjukan Stand-Up Comedy Special Pragiwaksono World Tour.

\section{Penetapan Strategi Komunikasi}

Dalam menjalankan strategi komunikasi pemasaran pertunjukan tersebut diperlukan langkah-langkah strategis untuk mengkomunikasikan pesan yang ingin disampaikan agar dapat disampaikan dengan efektif dan tetap sasaran.

Dalam melakukan kegiatan strategi pemasaran ini event ini seperti kegiatn dalam komunikasi pemsaran yang disampaikan oleh Cangara (2013 : 133) bahwa terdapat 14 langkah yang dapat digunakan untuk menyusun strategi komunikasi pemasaran, yaitu :

\section{Memilih dan Menetapkan Komunikator}

Dalam komunikasi pemasaran, pemilihan seorang komunikator yang baik sangat berpengaruh dalam keberhasilan komunikasi karena komunikatorlah yang harus memahami penyusunan penyampaian pesan hingga pendekatan pada target sasaran. Dalam komunikasi pemasaran Pragiwaksono World Tour, Pandji sendiri yang menjadi komunikator utama berdasarkan berbagai pertimbangan. Untuk menjadi komunikator terdapat tiga syarat yang harus dipenuhi, yaitu :

\section{a. Kredibilitas}

Semakin tinggi tingkat kredibilitas komunikator semakin tinggi pula tingkat kepercayaan publik terhadap komunikator tersebut. Pandji sebagai komunikator utama dipilih dengan pertimbangan bahwa Pandji memiliki kredibilitas yang cukup di bidang politik dan pelaku stand up komedi. Strategi komunikasi yang akan digunakan adalah untuk menarik asumsi masyarakat terhadap keterlibatan Pandji ke 
dalam dunia politik dianggap sesuai. Terlebih image Pandji dalam dunia politik sudah mulai terbentuk setelah Pandji menjadi juru bicara tim pemenangan calon gubernur DKI Jakarta Anies Baswedan dan Sandiaga Uno tahun 2017 lalu. Kesadaran ini diungkapkan langsung oleh Pandji dalam dalam proses pengumpulan data ini. Pandji mengakui keterlibatannya saat membantu pencalonan gubernur Anies Baswedan. Sebagaimana statemennya

"Iya, karena sempet bantuin mas Anies..." dilanjukan olehnya bahwa "...Di sisi lain, setiap kali Pandji ngomong apapun pasti dikait-kaitin lagi ke politik, ke pilkada.".

Kesuksesan Pandji dalam pemenangan Anies-Sandi memberikan citra baru pada dirinya terkait politik. Hal ini tergambar melalui tampilnya Pandji dalam berbagai media baik online maupun offline dalam proses kampanye politik kepala daerah Jakarta yang lalu.

\section{b. Daya Tarik}

Sebagai seorang entertainer, Pandji memiliki daya tarik sebagai orang yang aktif berkomunikasi dengan orang-orang yang mengikuti karyanya, terutama di media sosial. Seperti pada akun instagramnya, Pandji berusaha menyempatkan untuk membalas komentar-komentar yang muncul di unggahannya. Seperti yang dilakukan pada masa-masa kampanye pilihpandji.com, Pandji terlihat membalas komentar-komentar warganet.

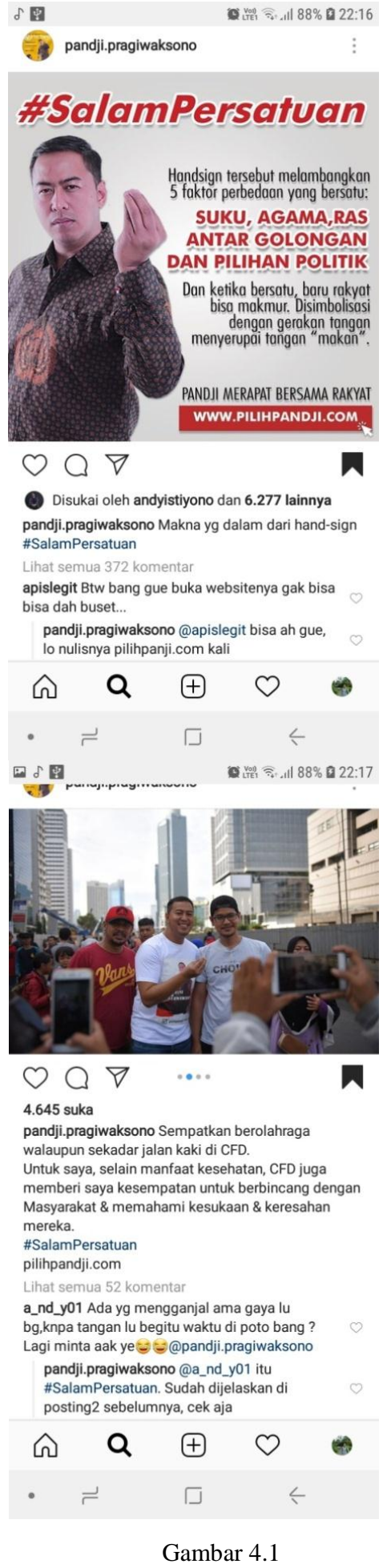

Screeshoot Pandji membalas komentar warganet pada akun Instagramnya

(sumber : instagram.com/pandji.pragiwaksono)

\section{c. Kekuatan}

Sebagai seorang komunikator utama kampanye pilihpandji.com, Pandji memiliki kekuatan dalam penyampaian pesan. Terlihat pada materi billboard dan materi-materi kampanye lain 
yang ditampilkan adalah ide yang diusulkan oleh Pandji sendiri. Menurut Pandji, dalam timnya Pandji memiliki kelebihan sebagai promotional strategist paling baik seperti yang disampaikan pada saat wawancara.

\section{Menetapkan Target Sasaran dan Analisis Kebutuhan Khalaya}

Pandji menggunakan marketing funnel (sebuah konsep yang menjelaskan tahapantahapan yang dilalui pembeli sebelum mengambil keputusan pembelian) sebagai pondasi dalam menetapkan target sasaran. Terdapat lima tahapan dalam marketing funnel yang digunakan oleh Pandji yaitu awareness, appeal, ask, arrive, act. Dalam setiap tahapan Pandji mengasumsikan hanya $10 \%$ orang yang akhirnya memutuskan untuk melanjutkan ke tahap selanjutnya. Target yang ingin dicapai adalah 5000 pembeli sehingga dengan perhitungan tersebut Pandji harus mendapatkan awareness dari 50 juta audience. Hal ini sesuai dengan pengakuan yang disampaikan pandji saat proses pengumpulan data

" saya itu kalo jualan itu percaya sama ada namanya marketing funnel. jualan itu kaya ngelihat corong, atasnya gede bawahnya kecil.....Karna waktu itu ngukur kalo ujung pengen dapet 5000 tiket.. maka ngambil selalu asumsi minimal. Misalkan 5000, 5000 tu 10\% nya berapa ...oh sekian"

Penggambaran Marketing Funnel ini dapat dijelaskan dalam bagan di bawah ini

MARKETING FUNNEL

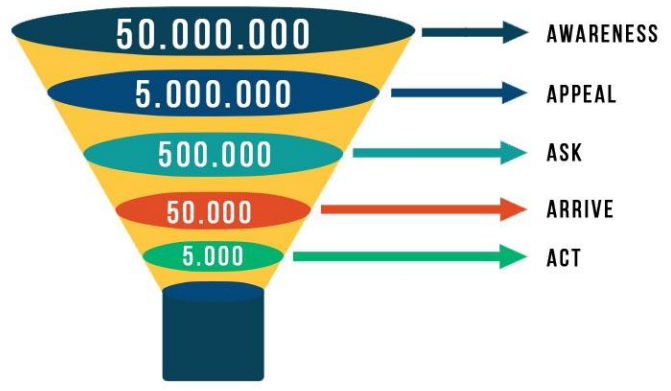

Gambar 4.2

Marketing funnel yang digunakan Pandji Pragiwaksono (sumber : hasil wawancara \& catatan narasumber)
Dalam Pragiwaksono World Tour target sasaran utama adalah khalayak dengan tingkat ekonomi menengah keatas. Alasan pertama penetapan target sasaran tersebut adalah karena harga tiket pertunjukan yang cukup mahal. Harga tiket yang dijual mencapai Rp.1.200.000,membuat target sasaran yang dituju adalah orangorang yang memiliki tingkat ekonomi yang cukup tinggi. "...target market saya itu kelas menengah keatas...". Dengan harga yang relatif tinggi tersebut Pandji berusaha untuk membantu konsumennya untuk mendapatkan tiket tersebut dengan memberikan waktu untuk mempersiapkan uang untuk membeli tiket dengan upaya promosi lebih lama.

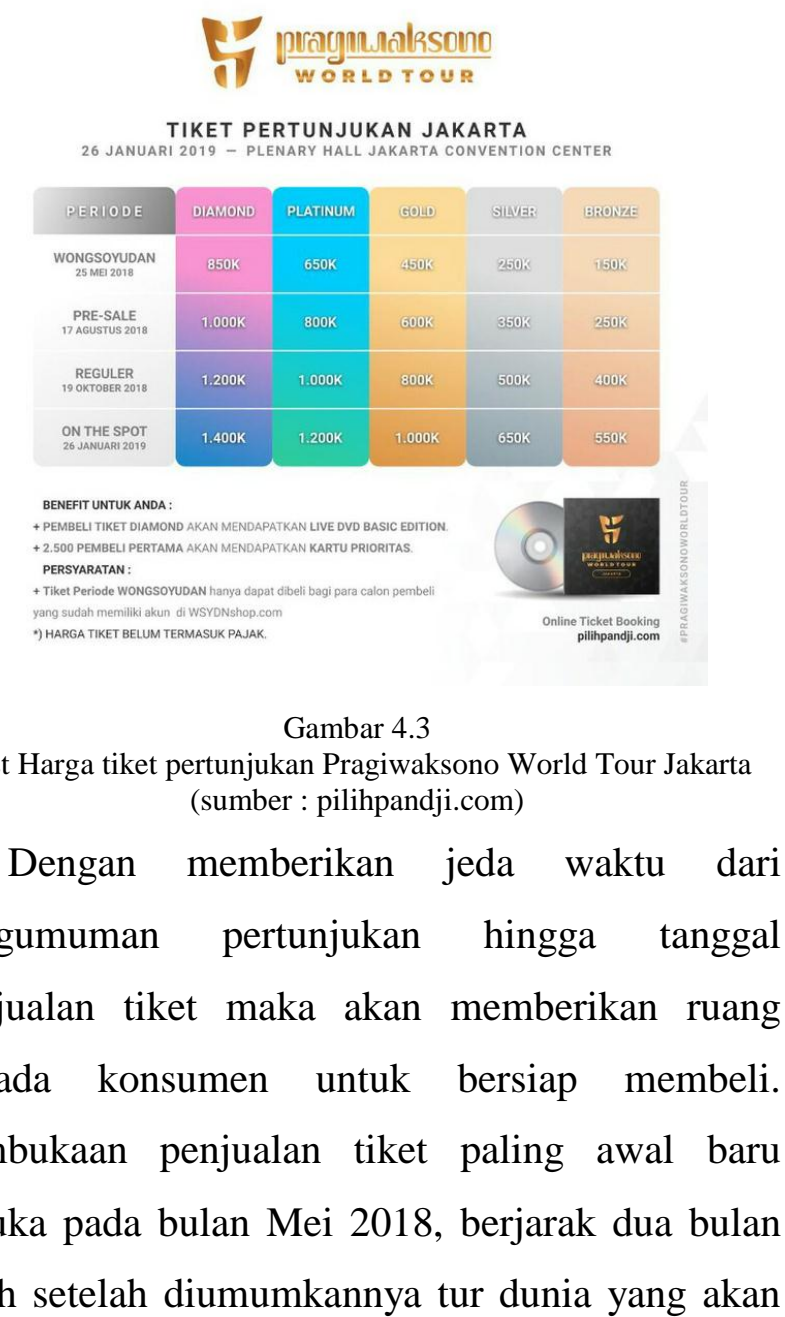


dilakukannya. Semua informasi seperti tanggal, tempat pertunjukan dan harga tiket sudah diinformasikan jauh hari sebelum pertunjukan dilaksanakan. Dengan cara seperti itu Pandji yakin konsumen akan lebih siap dan ketika tanggal penjualan tiket datang diharapkan para konsumen sudah siap mengantri untuk membeli tiket yang akan dijual.

\section{Teknik Menyusun Pesan}

Bukan hal yang mudah bagi Pandji untuk dapat mengkomunikasikan produknya kepada konsumen dikarenakan tahun 2017 hingga 2019 merupakan tahun yang cukup hangat dengan pemberitaan politik. Dengan arus politik yang kuat tersebut membuat Pandji sendiri memiliki asumsi bahwa publik enggan menonton pertunjukannya dikarenakan keterlibatannya dalam dunia politik menjadi tim pemenangan Anies Baswedan dan Sandiaga Uno dalam pilkada 2017 lalu, banyak meninggalkan pesan negatif atas dirinya di sebagian publik. "...Bahkan dari tahun 2017 itu nuansa politiknya di sosmed itu kenceng banget. Jadi kita bingung gimana cara ngelawannya ya ini ombak gede banget, susah banget dilawan..." kata Pandji. Bahkan dulu ada seorang manajer yang menyarankan Pandji untuk tidak membicarakan tentang politik lagi ke publik. Namun Pandji berfikir sebaliknya untuk memanfaatkan moment ini.

Dengan keyakinan untuk menaiki ombak politik, Pandji memanfaatkan fenomena artis nyaleg sebagai jalan untuk menarik perhatian publik. Ide dasarnya adalah untuk menarik perhatian (awareness) lebih dari 50 juta audience sesuai dengan rencana penetapan target sasaran. Akhirnya dibuatlah kampanye "Pilih Pandji" yang menampilkan Pandji seakan-akan mencalonkan diri sebagai caleg dan terjun secara penuh ke dunia politik. Namun tidak menampilkan berbagai atribut penting dalam pencalonan seperti layaknya pencalonan resmi seperti DAPIL (daerah pilihan), partai pengusung dan nomor urut caleg. Hal ini untuk membangun asumsi publik bahwa dirinya akan nyaleg dan pembicaraan tentang hal tersebut yang diinginkannya. Hal ini terlihat dalam contoh unggahan-unggahan yang ditampilkan pada akun Instagramnya tidak ada satupun dari atribut politik yang ditampilkan.

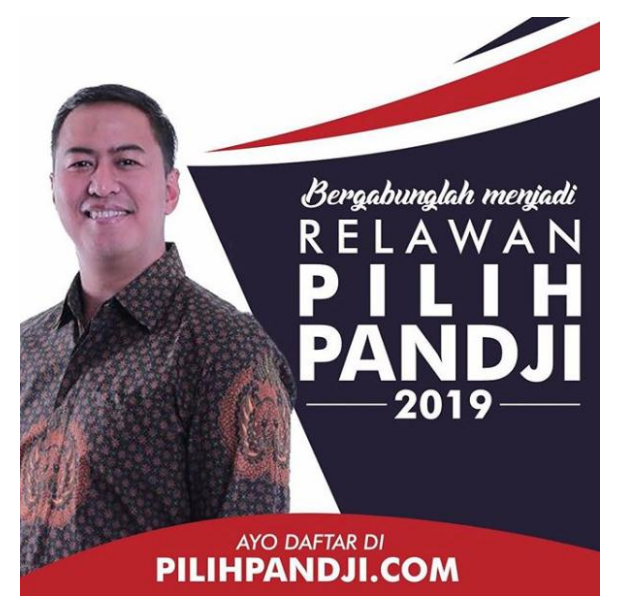

Gambar 4.4

Screenshoot unggahan Pandji dalam akun Instagram miliknya (sumber : instagram.com/pandji.pragiwaksono)

\section{Memilih Media atau Saluran Komunikasi}

Dalam menjalankan strategi komunikasinya, Pandji membutuhkan media yang dapat meyakinkan audience dengan pesan yang ingin disampaikan terkait pura-pura nyaleg. Media tersebut haruslah media yang dapat dilihat oleh masyarakat luas dan memicu khalayak untuk bereaksi terhadap pesan dalam media tersebut. Media pertama yang dipilih untuk mengundang 
reaksi khalayak adalah billboard. Menurut Pandji

billboard dipilih karena akan lebih serius ditanggapi sebagai sebuah tindakan nyaleg ketimbang hanya menaruh di media sosial atau poster-poster kecil yang dipasang di pohon-pohon. Disebutkan oleh Pandji bahwa "Kalo bohong mesti total, kalo setengah-setengah gada yang percaya”. Maka dari itu pemasangan billboard dipilih untuk menyebarkan pesan tersebut, yang salah satunya terpasang di daerah cihampelas Bandung.

Pemasangan billboard awalnya direncanakan pada 3 kota yang memiliki tingkat keaktifan warganet yang tinggi yaitu Jakarta, Bandung dan Yogyakarta, namun karena berbagai kendala akhirnya diputuskan billboard tersebut untuk dipasang di Bandung yang tetap dilewati oleh konsumennya dan billboard kedua dipasang di Yogyakarta.

Media kedua yang dipilih adalah website. Alamat web tersebut terpampang jelas di kedua billboard yang dipasang di Bandung dan Yogyakarta. Dengan memilih nama domain pilihpandji.com Pandji kembali mencoba mengarahkan asumsi publik dengan membuat nama yang sekan-akan mengajak audience untuk mendukungnya dalam pemilihan umum.

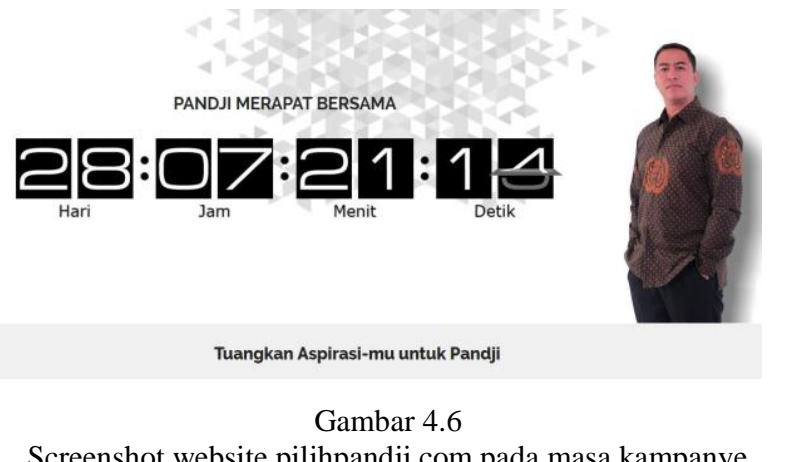

Screenshot website pilihpandji.com pada masa kampanye (sumber : pilihpandji.com)
Website dipilih sebagai salah satu media yang dipakai dalam mengkomunikasikan kampanyenya atau lebih tepatnya adalah alat untuk menampung seluruh reaksi khalayak dan mengukur seberapa jauh hasil penyebarluasan materi komunikasi yang telah dilakukan.

Namun sebenarnya sebelum billboard dan website tersebut muncul ke publik. Pandji sudah mulai menggiring opini warganet melalui kanal Youtubenya yang dengan sengaja memuat beberapa video yang selalu diakhiri seolah memberikan kesan bahwa Pandji akan mulai membicarakan politik lagi melalui akun pribadinya tersebut.

"Iya, sengaja (mengarahkan opini). Ketika saya putuskan saya mau bikin kampanye pilihpandji.com saya tau di Youtube juga saya harus kembali ngomongin politik...".

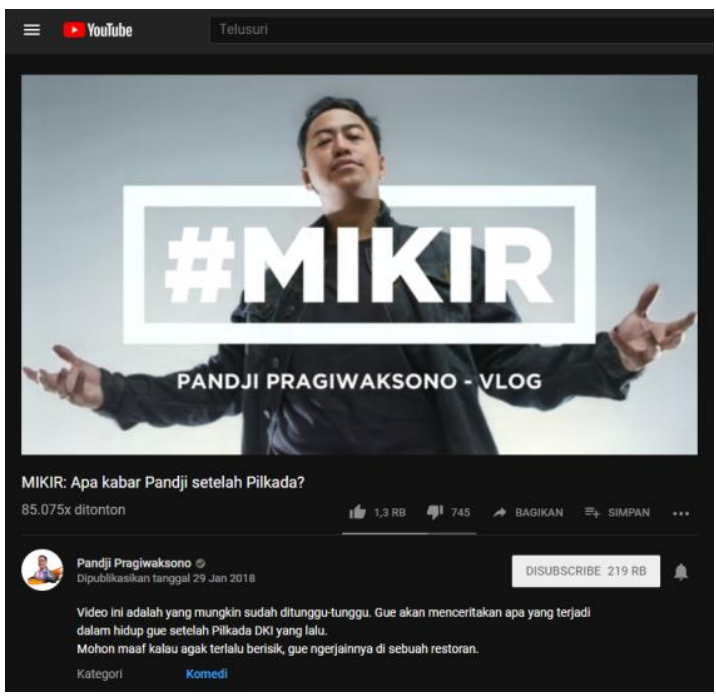

Gambar 4.7

Screenshoot unggahan video pada kanal Youtube Pandji Pragiwaksono

(sumber : https://www.youtube.com/watch?v=Wjf2zu3HwEw\&t)

Salah satu video yang diunggah adalah video berjudul "MIKIR : Apa kabar Pandji setelah Pilkada?". Dimulai pada pengunggahan video tersebut Pandji sudah mulai mengarahkan opini 
publik ke arah kampanye yang akan diumumkan beberapa waktu kedepan.
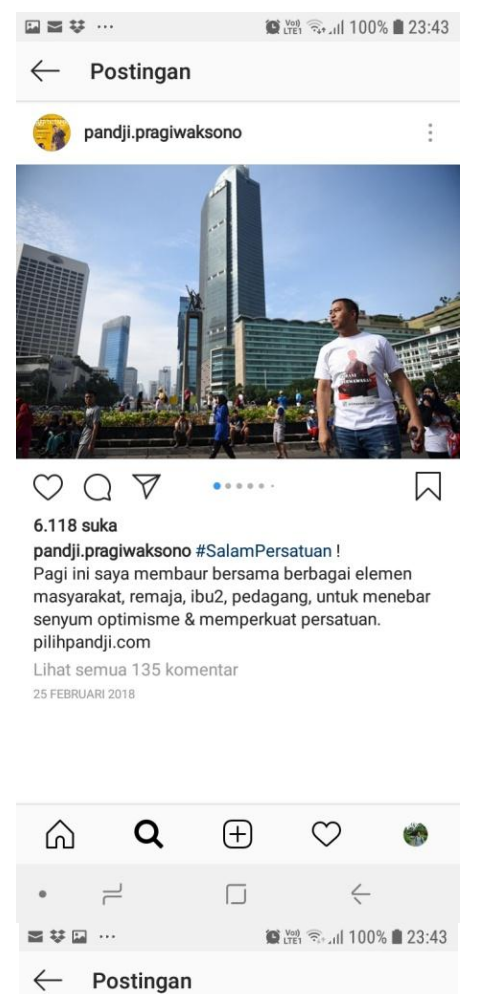

$\leftarrow$ Postingan
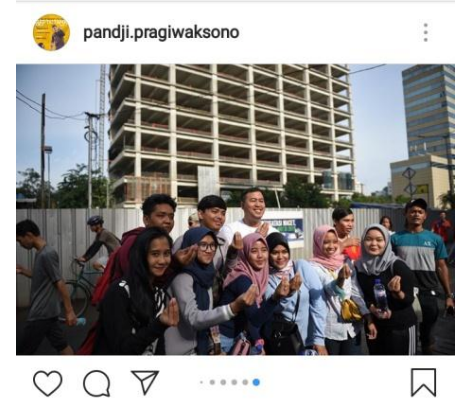

6.118 suka

pandji.pragiwaksono \#SalamPersatuan!

Pagi ini saya membaur bersama berbagai elemen

masyarakat remaja, ibu2, pedagang, untuk menebor senyum optimisme \& memperkuat persatuan. pilihpandji.com

Lihat semua 135 komenta

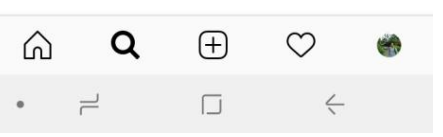

Gambar 4.8

Screeshoot Pandji berfoto dengan masyarakat yang diunggah pada akun Instagramnya

(sumber : instagram.com/pandji.pragiwaksono)

Media sosial lain yang pakai dalam kampanye kegiatan pemasaran eventya adalah Instagram. Terdapat beberapa unggahan termasuk diantaranya unggahan foto bersama masyarakat Kota Jakarta saat CFD di kawasan bundaran HI dengan berbagai pose.

\section{Telepon Selular dan SMS}

Perkembangan teknologi yang cukup pesat membuat alat komunikasi yang digunakan menjadi semakin murah dan semakin memiliki banyak pilihan. Sambungan telepon dan SMS merupakan salah satu cara berkomunikasi yang sudah lama digunakan dan mulai tergantikan dengan sarana komunikasi lainnya seperti aplikasi pengirim pesan dan media sosial yang menggunakan jaringan internet. Pada wawancara yang dilakukan peneliti, Pandji lebih banyak menggunakan aplikasi Whatsapp, LINE dan Instagram untuk keperluan komunikasi selama masa kampanye pilihpandji.com.

\section{Produksi Media}

Pada kampanye pilihpandji.com terdapat beberapa jenis materi komunikasi yang diproduksi diantaranya media luar ruang billboard, materi audio visual dan materi komunikasi yang diunggah pada media sosial (gambar dan foto). Dalam memproduksi materi komunikasi tersebut Pandji banyak melakukannya sendiri terutama yang tidak memerlukan sebuah desain seperti pembuatan video yang diunggah dalam channel Youtubenya selalu direkam sendiri. Beberapa unggahan pada media sosial lainnya juga Pandji lakukan sendiri melalui ponsel pribadinya. Namun pada konten-konten yang memerlukan sebuah desain seperti yang terpasang pada billboard, Pandji mempercayakannya kepada seorang ilustrator yang memang sudah sejak lama 
membantunya mengerjakan berbagai projek desain. Orang ini juga yang membantu, tidak hanya selama kampanye pilihpandji.com namun hingga keseluruhan desain Pragiwaksono World Tour.

\section{Uji Awal Materi Komunikasi}

Setelah materi-materi komunikasi selesai dibuat tidak ada pengujian awal materi komunikasi yang dilakukan oleh Pandji sebelum menyebarluaskannya. Pandji hanya mengandalkan orang-orang tertentu dalam lingkupnya untuk menanyakan pendapatnya tentang materi yang sedang dibuatnya.

\section{Penyebarluasan Media Komunikasi}

Sesuai dengan rencana penyebarluasan materi komunikasi, yang membuat khalayak tertipu pertama kali adalah pemasangan billboard. Namun sebelum pemasangan billboard-billboard tersebut sebenarnya Pandji sudah mencoba memberikan pesan tersirat melalui video-video yang ia unggah di kanal Youtubenya.

Dimulai dari video berjudul "MIKIR : Apa kabar Pandji setelah Pilkada?" Pandji mengungkapkan bagaimana hari-hari yang dijalaninnya, karirnya, keuangannya dan berbagai hal lainnya pasca pilkada dan pada akhir video Pandji dengan "sengaja" mengajak penonton untuk menonton video selanjutnya tentang "Kenapa Pandji udah gak pernah ngomongin Politik?". Sesuai judulnya video tersebut berisi alasan Pandji tidak pernah berkomentar lagi pasca pilkada 2017 lalu dan kembali di akhir video ia menyampaikan pesan tersirat yang mengungkapkan bahwa dirinya akan aktif kembali membicarakan masalah politik beserta alasannya.

Pengarahan asumsi publik kembali terlihat ketika Pandji mengatakan kalimat berikut :

"...Sekarang udah waktunya, karena kedepan gua akan lebih sering ngomongin soal politik, akan lebih gencar ngomongin soal politik kaitannya sama sesuatu yang akan gua umumkan dalam waktu dekat. Ini sesuatu yang sudah diminta kepada gue sejak lama. Banyak yang minta ini ke gue. Gua denger aspirasinya... ".

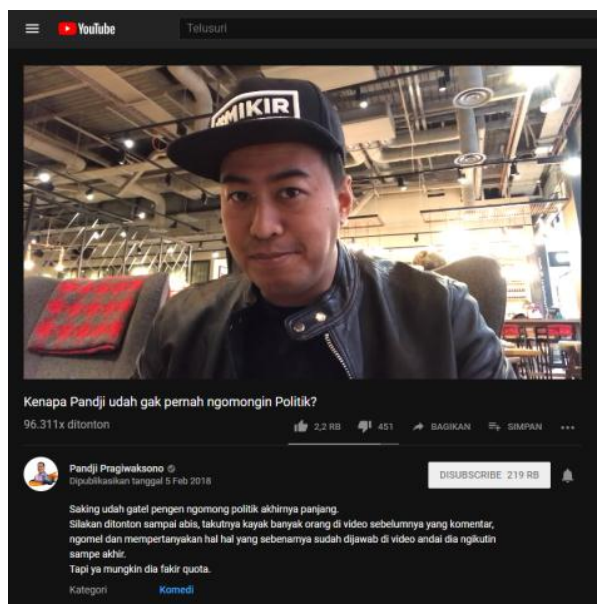

Gambar 4.9

Screenshoot unggahan video pada kanal Youtube Pandji Pragi (sumber : https://www.youtube.com/watch?v=TkixulDLDIU\&t)

Dilanjutkan pada video berjudul "Kenapa Ahok Kalah?" Pandji kembali menyelipkan katakata yang menarik asumsi publik yaitu "...kalo gue sih ngurusin campaign gua sendiri,..." dan di video ini juga pertama kalinya Pandji menunjukan handsign salam persatuan. Setelah selesai dengan video-video tersebut barulah Pandji memasang billboard yang akhirnya meramaikan dunia maya selama 1 bulan. 


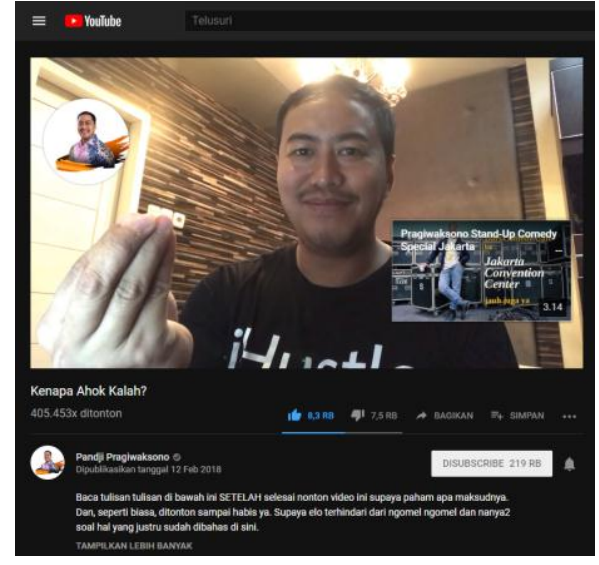

Gambar 4.10

Screenshoot unggahan video pada kanal Youtube Pandji Pragi (sumber : https://www.youtube.com/watch?v=hAzxl--j3oI\&t)

Seperti yang sudah dijelaskan sebelumnya pemasangan billboard akhirnya dilakukan pada dua kota yaitu Bandung dan Yogyakarta. Pemilihan dua kota tersebut bukan tanpa dasar, menurut Pandji kedua kota tersebut merupakan kota-kota yang memiliki warganet paling aktif yang sangat dibutuhkan komentar nitizen untuk menaikkan perbincangan. Bandung menjadi salah satunya, walaupun Kota Bandung tidak menjadi kota diadakannya pertunjukan stand-up comedy specialnya kali ini dengan pertimbangan harga pemsangan baliho, tingkat kepadatan lalu lalang orang akhirnya Bandung dijadikan salah satu tempat pemasangan billboardnya agar diperbincangkan.

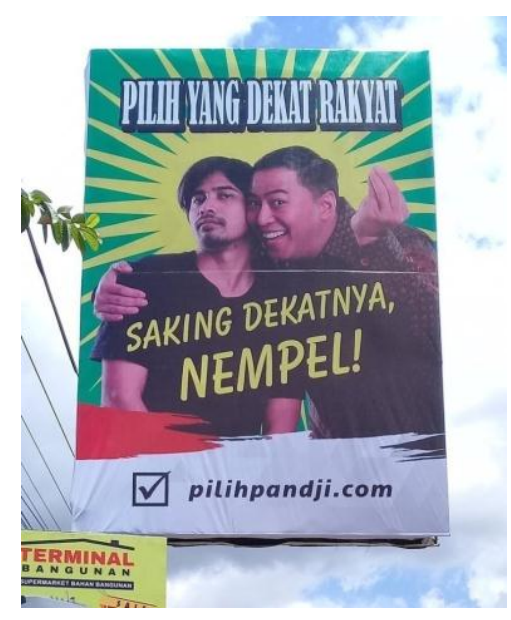

Gambar 4.11

Contoh Billboard Stand Up Comedy Special Pragiwaksono (sumber :https://twitter.com/pandji/status/966211281278722048)

Pemasangan billboard kedua yaitu di Yogyakarta, pesan pada billboard yang sangat sederhana dan berisikan beberapa kata saja. Dengan asumsi bagi khalayak yang ingin mendapat informasi lebih banyak maka peran dari alamat website yang terpampang pada kedua billboard akan membantu. Dalam website tersebut pengunjung halaman dipaksa untuk semakin meyakini akan keterlibatan Pandji ke dalam dunia politik dengan dua kalimat dan sebuah countdown di hompage web tersebut seperti mengisyaratkan akan mengumumkan keputusannya setelah hitungan mundur tersebut berakhir. Dengan media-media tersebut Pandji berharap dapat membangun awareness masyarakat dan memicu reaksi warganet melalui berbagai media sosial.

Media sosial juga secara langsung menjadi alat penyebar pesan otomatis karena reaksi khalayak. Sesaat setelah Pandji memasang billboard, pada hari yang sama pula unggahan berupa foto billboard tersebut mulai tersebar di berbagai media sosial seperti Facebook, Instagram dan Twitter.

Untuk menguatkan asumsi khalayak, Pandji juga mengunggah konten-konten bernuansa kampanye pada beberapa akun media sosialnya. Di Instagram, demi meningkatkan kepercayaan publik atas kebohongannya Pandji mengunggah beberapa konten berbau kampanye seperti mengunggah materi kampanye yang sama seperti yang terpasang di billboard Bandung, berfoto bersama dengan pengunjung CFD (car free day) 
di kawasan bundaran HI Jakarta dan berfoto bersama salah satu kader partai tertentu.

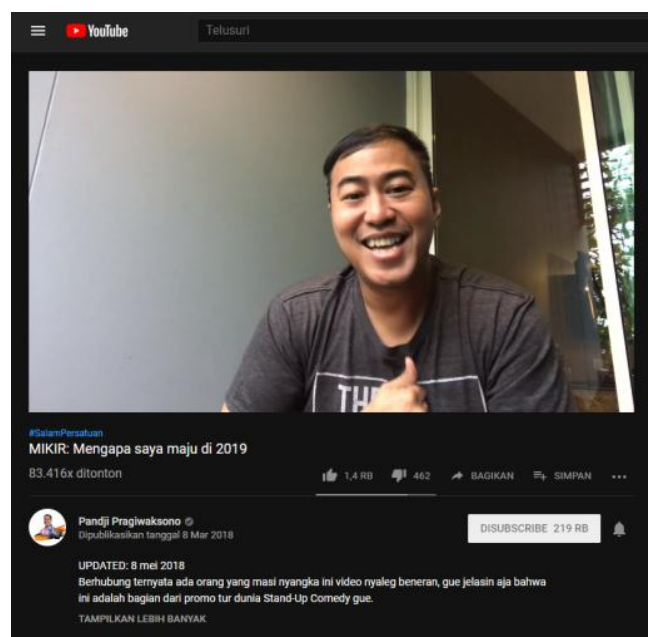

Gambar 4.12

Screenshoot unggahan video pada kanal Youtube Pandji Pragiwaksono

(sumber : https://www.youtube.com/watch?v=NiVG8smaHUs\&t)

Melalui kanal Youtubenya juga Pandji kembali mengunggah sebuah video dengan judul " MIKIR : Mengapa saya maju di 2019" yang berisikan berbagai alasannya untuk "maju di 2019” yang dipakai untuk mengarahkan opini masyarakat untuk berfikir bahwa video tersebut sebagai salah satu bentuk keseriusan pencalonan Pandji sebagai anggota legislatif.

\section{Menganalisis Efek Komunikasi}

Mempengaruhi target sasaran adalah tujuan komunikator dalam menjalankan program komunikasi. Pengaruh yang dapat dilihat adalah perbedaan yang terjadi antara apa yang dipikirkan, dilakukan dan dirasakan oleh penerima pesan. Efek komunikasi pemasaran yang dihasilkan dari kampanye pilihpandji.com dapat dibilang cukup besar. Dimulai dari 3 video yang diunggah Pandji sebelum memasang billboard yaitu video "MIKIR : Apa kabar Pandji setelah Pilkada?" dengan 85 ribu viewers, "Kenapa Pandji udah gak pernah ngomongin Politik?" yang memiliki 96 ribu viewers dan video "Kenapa Ahok Kalah?” yang mendulang 405 ribu viewers dapat dibilang memiliki hasil yang cukup bagus dengan menarik cukup banyak penonton.

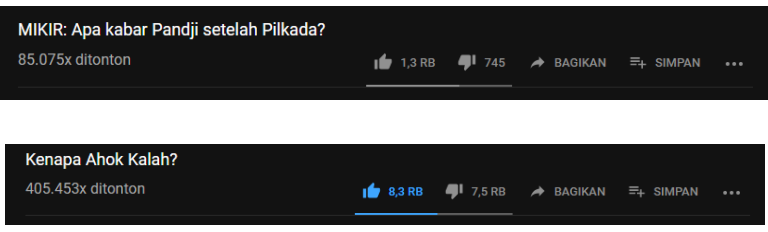

Gambar 4.13

Screenshoot jumlah penayangan video di Youtube Pandji Pragi (sumber : https://www.youtube.com/user/pandjimusic)

Kolom komentar pun juga dipenuhi dengan sanggahan-sanggahan warganet yang memiliki bebagai pandangan berbeda dengan Pandji maupun para pendukungnya namun secara prosentase lebih banyak warganet yang tidak sejalan dengannya dan akhirnya melontarkan banyak komentar negatif namun justru hal itulah yang diinginkan dan membuat namanya semakin naik dan dikenal banyak orang.

Dari beberapa media sosial popular yang ada, Twitter menjadi yang paling cepat menyebarkan berita tersebut. Beberapa jam setelah pemasangan billboard sudah mulai tampak unggahan-unggahan foto dan komentar warganet terhadap billboard tersebut. Ditambah dengan handsign yang diciptakan oleh Pandji yaitu salam persatuan. Handsign salam persatuan merupakan ide kedua yang terfikirkan oleh Pandji untuk meningkatkan reaksi khalayak terhadap kampanyenya.Handsign ini merupakan tanda limajari dalam satu tangan berkumpul . Dengan filosofi makna yang ditambahkan yang mana mengandung nilai persatuan, Handsign salam persatuan ini dimaknai Pandji sebagai lima elemen masyarakat Indonesia 
yang perlu disatukan yaitu ras, suku, agama, antargolongan serta pilihan politik (SARAP).

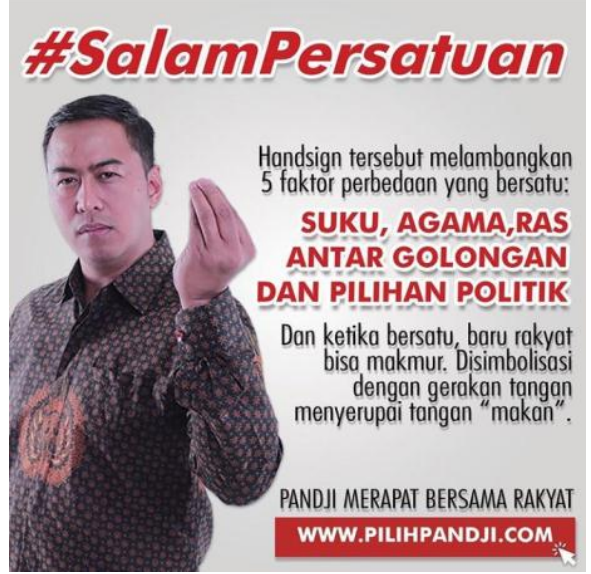

Gambar 4.14

Screeshoot Materi komunikasi dengan pose salam persatuan (sumber : instagram.com/pandji.pragiwaksono)

Handsign tersebut terus digunakan oleh Pandji selama masa kampanye pilihpandji.com dan menjadi lebih viral di media sosial ketika Pandji memutuskan untuk datang ke area CFD (car free day) di area bundaran HI. Dengan memakai kaos kampanyenya ia berkeliling area CFD dan berfoto dengan masyarakat menggunakan pose salam persatuan. Menurut Pandji dengan berfoto dengan masyarakat tersebut dapat menambah popularitas kampanyenya.

Semakin viralnya aktifitas kampanye Pandji, tidak hanya menjadi obrolan di dunia maya dengan khalayak umum namun hingga merambah ke lingkaran pertemanan. Bahkan orang-orang yang mengenal Pandji secara personal banyak yang tidak tahu akan "kebohongan" yang sedang dilakukannya.Hal ini seperti yang sengaja diungkapkannyadalam sesi wawancara

“...Saya lakuin, fotonya viral ditambah yang ada handsign itu diketawain orang.Bahkan masuk grup Whatsapp temen-temen kampus,diketawain saya, sama sekali ga ngeh bahwa itu strategi, bukan nyaleg..."

Seminggu sebelum pengumuman "kampanye" pandji memutuskan untuk menaikkan kembali pembicaraan tentang dirinya dengan berfoto dengan beberapa kader suatu partai.

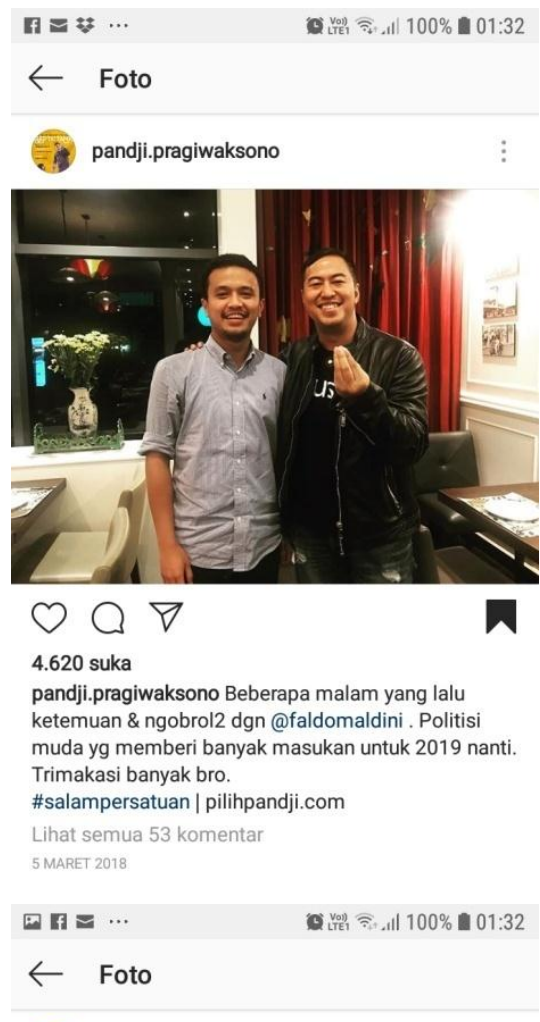

pandji.pragiwaksono

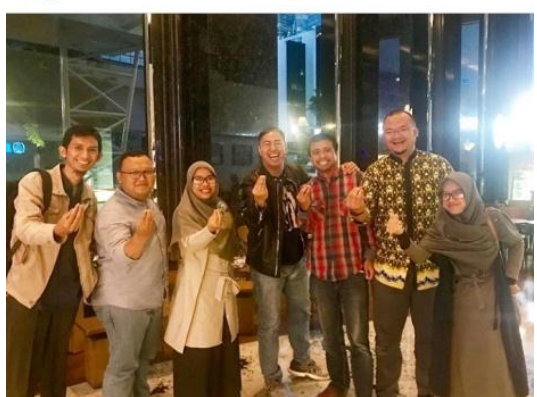

$\odot \bigcirc \nabla$

6.212 suka

pandji.pragiwaksono Bertemu, berdiskusi \& menca kesepahaman.Bro@JaLdeee sampaikan salam kepada Pak@msi.sohibuliman. Silaturahmi akan disegerakan :) \#SalamPersatuan | pilihpandji.com Lihat semua 187 komentar

12 MARET 2018

Gambar 4.15

Screeshoot foto Pandji Pragiwaksono dengan anggota partai (sumber : instagram.com/pandji.pragiwaksono)

Kader partai pertama yang diincar Pandji adalah temannya sendiri, Faldo Maldini yang 
berasal dari PAN, namun usahanya tersebut kurang membuahkan hasil lalu diputuskan untuk berfoto dengan kader partai yang menurut Pandji secara umum kurang disukai oleh warganet yaitu PKS. Akhirnya setelah muncul foto Pandji bersama kader PKS kampanyenya kembali viral bahkan lebih ramai ketimbang sebelumsebelumnya.

"... kebetulan temen saya Faldo dari PAN . Saya lagi nyari premis stand-up dari dia, tentang stand-up comedy. Saya foto pakai (Salam persatuan)setelah diunggah orang berasumsi, "oh si Pandji ngerapetnya ke PAN nih". kurang viral, trus saya cari strategi lain Partai apa ya yang pasti bakal viral ama netizen, dalam pikiran saya PKS, Jadi saya ajak anak-anak PKS ketemuan, ngobrol...terakhirnya saya foto. Itu H minus 1,diunggah dan ruuaammee."

Foto itulah yang membuat lebih banyak orang semakin penasaran dengan countdown yang terpampang dalam halaman web pilihpandji.com. Pada keesokan harinya setelah semua orang penasaran terhadap keputusan Pandji, baru terungkaplah bahwa semua kampanye tersebut hanyalah sensasi yang diciptakan untuk menarik perhatian publik terhadap pertunjukan yang akan digelarnya. Seketika itu juga warganet yang membencinya menghilang karena mengetahui ini bagian dari strategi Pandji.

Setelah semua "kebohongan" yang Pandji tampilkan terungkap, banyak warganet yang menjadi tertarik dengan pertunjukan yang akan diadakan. Ditambah dengan bantuan yang sebelumnya dibahas pada tahap kedua, membuat penjualan tiket pertunjukan menjadi membludak. Dampak dari "bantuan" yang diberikan Pandji kepada konsumennya tersebut sukses membuat website penjualan tiket menjadi tidak dapat diakses sementara waktu karena tingginya animo konsumen. Dari rencana 2500 tiket pertunjukan di Jakarta yang akan dijual dalam waktu satu bulan ternyata habis terjual dalam waktu satu hari dan bahkan penjualan tiket melebihi target dengan 4000 tiket terjual di hari yang sama. "Iya, makanya jebol. Harusnya periode pertama cuma jual 2500 tiket, kejual 4000 tiket dalam satu malam."

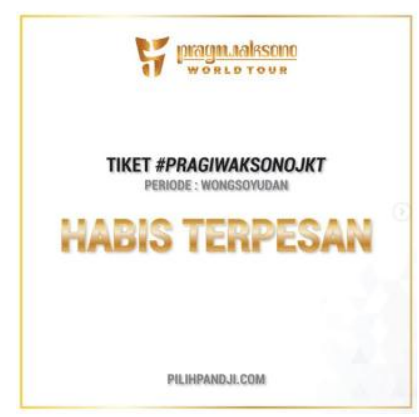

Gambar 4.16

Screenshoot penjualan tiket Pragiwaksono Jakarta (sumber :instagram.com/pandji.pragiwaksono)

Hal tersebut membuktikan argumen yang ingin disampaikan Pandji adalah benar bahwa konsumen sebenarnya ingin membeli produk yang dijual asalkan konsumen juga dibantu untuk mempersiapkan diri dari sisi keuangan seperti yang dilakukan oleh Pandji dan hal ini juga sesuai dengan teori yang disampaikan oleh Hafied Cangara (2013 : 133) dalam penetapan strategi komunikasi.

\section{Penetapan Rencana Anggaran}

Dalam hal penganggaran, Pandji melakukan beberapa penekanan pengeluaran biaya, salah satunya dengan tidak beriklan pada media massa seperti televisi, radio bahkan surat kabar. Untuk itu dirinya mengatasinya melalui pemanfaatan momentum pembincangan tentang Pemilu atau 
Pilihan legislatig. Hal itu kemudian memunculkan anggaran belanja pemasangan pada billboard, pada titik yang dianggap tepat.

Selain itu Pandji memanfaatkan media digital sebagai bagian dari strateginya karena relative murah. Disebutkan bahwa dirinya memanfaatkan fasilitas periklanan di media sosial Instagram dengan anggaran belanja komunikasi sebesar Rp. 500.000,-. Media ini dipilih karena lebih terukur dengan jelas interaksi yang terjadi didalamnya.

\section{Penyusunan Jadwal Kegiatan}

Jadwal kegiatan promosi pemasaran event Stand Up comedy Panji Pargiwaksono World Tour yang di beri label kampanye pilihpandji.com sudah dimulai sejak Januari 2018 dimana Pandji mengunggah video pertama kali dikanal Youtubenya pada 29 Januari 2018 dan dua video lain pada 5 dan 12 Februari 2018. Setelah itu pada 15 Februari mulai memasang billboard di Bandung yang mana menandakan resminya kampanye pilihpandji.com dimulai. Dan selama 1 bulan membuat publik maya ramai, dilanjutkan dengan pengumuman menginformasikan tur dunianya, mulai dari kota-kota diadakannya pertunjukan, harga tiket, kapasitas area pertunjukan dan sebagainya.

\section{Penetapan Tim Kerja}

Tim yang dapat diandalkan sangat diperlukan dalam kesuksesan suatu kegiatan. Tak terkecuali stand-up comedy special Pragiwaksono World Tour yang diadakan di 5 negara yang berbeda. Pada dasarnya Pandji memiliki tim manajemen tersendiri untuk dapat menangani acara ini, namun untuk tiap kota diadakannya pertunjukan ada tim lokal untuk membantu pelaksanaan pertunjukan. Apalagi pada penutup tur dunia kali ini diadakan di venue yang mampu menampung lebih dari 5000 orang didalamnya, tentu membutuhkan tim dengan jumlah yang tidak sedikit. Disebutkan oleh Pandji setidaknya terdapat hampir 200 orang yang tergabung ke dalam tim pelaksana terutama pada relawan hari $H$. Panggung pada pertunjukan Pragiwaksono Jakarta membutuhkan tim dalam jumlah banyak karena pembangunan area penontonnya yang sebisa mungkin di desain untuk ramah difabel sehingga perlu di tata ulang sesuai kebutuhan. Selain itu terdapat head project dan asistennya, bagian sound, IT dan lain-lain. Untuk tim marketing ternyata Pandji hampir mengurus semuanya sendiri . "Saya promotional strategist paling baik di tim saya dan juga sales. Tim saya isinya ya manajemen tapi gada orang promo.".

\section{Evaluasi dan Audit Komunikasi}

Pada proses kampanye dalam memasarkan pertunjukannya, Pandji melakukan evaluasi terhadap komponen-komponen yang berhubungan dengan aktivitas tersebut. Alat ukur kesuksesan kampanye ini menurut Pandji adalah melalui sistem perhitungan pengunjung pada website pilihpandji.com.

"Sukses atau tidaknya kampanye pilih Pandji itu diukur dari, ada website pilihpandji.com. Kalau countdownnya angkanya sesuai dengan yang kami cari berarti sesuai target atau sesuai sasaran..."

Namun perhitungan yang ada hanya dapat ukur jumlah finalnya pada akhir timeline kampanye. Untuk itu, dalam proses berjalannya kampanye, Pandji memanfaatkan pembacaan 
sentimen warganet di media sosial evaluasi strategi yang berjalan.

Pada awal pengukuran ini, proses yang terjadi sesuai dengan tujuan, yakni meningkatkan awareness para calon konsumen terhadap Pandji. Namun ditengah berjalannya, setelah Pandji merespon orang-rang yang menghubunginya, ternyata umpan balik warganet mulai menurun. Padahal dalam statement Pandji, dirinya telah melakukan manufer mengenai keikutsertaannya dalam pemilihan legislatif dengan menyampaikan,

Melihat adanya hambatan melalui hasil evaluasi pada interaktifitas warganet di media sosial, Pandji kemudian melakukan modifikasi dengan membentuk tim baru, yang beranggotakan para penikmat karyanya yang sudah militant dalam tin Saracin bentukannya. Modifikasi ini digunakan agar tujuan awal, strategi komunikasi tetap berjalan, yakni melalui pematahan anggapan bahwa Pilih Pandji bukanlah kampanye yang sebenarnya.

Selain untuk mengarahkan opini audience, tujuan pembentukan tim ini adalah untuk menciptakan kebingungan para pembaca (yang tidak beropini), sehingga tidak muncul penguatan terhadap statement 'ini bukan kampanye politik'. Modifikasi dengan memanfaatkan data yang ada ini menurut Pandji akan lebih menguntungkan, daripada mendiamkan interaktifitas audience yang terjadi.

Melalui improvisasi ini, tim Saraciiiiin mengarahkan, serta memperkuat anggapan bahwa Pilih Pandji merupakan usaha kampanye pencalonan legislatif.

\section{SIMPULAN}

Tahapan strategi komunikasi pemasaran yang dilakukan oleh team Pandji Pragiwaksono dalam memasarkan event Stand-Up Comedy Pandji Pragiwaksono World Tours menggunakan tahapan melalui perencanaan yang sudah dipikirkan secara matang. Hampir keseluruhan tahapan komunikasi pemasaran dilakukan dalam kampanye Pilih Pandji seperti yang dikemukan dalam konsep strategi pemasaran komunikasi oleh Cangara. Antara lain yaitu: (1) Memilih dan Menetapkan Komunikator dengan baik (2) Menetapkan Target Sasaran dan Analisis Kebutuhan Khalayak dengan menggunakan marketing funnel untuk menghitung jumlah audience yang ingin dijangkau. (3)Teknik Menyusun Pesan, dengan menggunakan pendekatan ala kampanye politik..(4) Media utama yang dipilih sebagai saluran komunikasi adalah billboard dan website pilihpandji.com. Media sekunder yang dipakai adalah media sosial seperti Youtube dan Instagram dengan menggunakan media berupa gambar, foto dan video. (5) Pandji dan team dalam pemasaran eventnya tidak melakukan uji awal materi komunikasi dan hanya menanyakan pendapat kepada orang-orang tertentu dalam lingkupnya. (6) Penyebarluasan Media Komunikasi, pertama kali dilakukan pada kanal Youtube dilanjutkan dengan pemasangan billboard di Bandung dan Yogyakarta, website pilihpandji.com serta media sosial Instagram. (7) Menganalisis Efek Komunikasi dan memobilisasi kelompok berpengaruh. besarnya efek komunikasi yang 
disampaikan dipengaruhi oleh beberapa hal diantaranya adalah handsign salam persatuan, foto dengan beberapa kader partai dan para warganet yang membenci Pandji.. (8) Penetapan Rencana Anggaran yang matang (9) Penyusunan Jadwal Kegiatan yang terencana (10) Penetapan Tim Kerja, baik tim inti yang selalu membantu dirinya selama tur, juga terdapat tim lokal yang membantu selama acara. (11) Evaluasi dan Audit Komunikasi. Pandji melakukan evaluasi terhadap komunikasi yang dilakukan,dan menggerakkan timnya tambahan yang bernama kelompok Saracin, untuk mematahkan asumsi warganet yang tidak menguntungkan atas program yang sudah dirancangnya.

\section{DAFTAR PUSTAKA}

Buku :

Ari Setiyaningrum, Juuf Udaya, Efendi. (2015). Prinsip-Prinsip Pemasaran Plus Tren Terkini. Yogyakarta : Andi Offset

Bungin, Burhan. (2007). Penelitian Kualitatif : Komunikasi, Ekonomi, Kebijakan Publik dan Ilmu Sosial Lainnya. Jakarta : Putra Grafika

Cangara, Hafied. (2013). Perencanaan \& Strategi Komunikasi. Jakarta : Rajawali Pers

Effendy, Onong Uchjana. (2006). Ilmu Komunikasi : Teori dan Praktek. Bandung : Remaja Rosdakarya

Kriyantono, Rachmat. (2014). Teknik Praktis Riset Komunikasi. Jakarta : Prenadamedia Group

Nugroho, Panji. (2012). Potret Stand Up Comedy :Strategi Menjadi Comedian Handal. Yogyakarta : Pustaka Baru Press.

Pawito. (2008). Penelitian Komunikasi Kualitatif. Yogyakarta :LKiS Group

Philip Kotler, Gary Armstrong. (2012). Prinsip-prinsip Pemasaran. Jakarta :Erlangga
Phillip Kotler, Gary Armstrong. (2012). Principle of Marketing $14^{\text {th }}$ edition. New Hall

Jerse: Prentice

Pragiwaksono, Pandji. (2012). Merdeka Dalam Bercanda. Yogyakarta: Bentang Pustaka

\section{Internet :}

20 September, Penetapan Capres-Cawapres untuk Pilpres 2019. (2018). Dalam https://nasional.kompas.com. Diunduh pada 30 Desember 2018 pukul 20.35 WIB

Bhinneka Tunggal Tawa. (2011). Dalam http://pandji.com/standupspecial. Diunduh pada 30 Desember 2018 pukul 19.20 WIB

Daftar 91 CalegArtis DPR RI di Pileg 2019. (2018). Dalam https://kumparan.com Diunduh pada 30 Desember 2018 pukul 21.00 WIB

Definition of Marketing. (2013). Dalam https://www.ama.org. Diunduh pada 30 Oktober 2018 pukul 20.40 WIB

INFOGRAFIK: Serba-serbi Caleg DPR RI Peserta Pileg 2019 dalam Angka.(2018). https://nasional.kompas.com. Diunduh pada 30 Desember 2018 pukul 20.40 WIB

Info Merdeka Dalam Bercanda Comedy Tour. (2012). Dalam https://pandji.com/turmdb. Diunduh pada 30 Desember 2018 pukul 19.35 WIB

Info tur Mesakke Bangsaku. (2013). Dalam http://pandji.com/info-mb. Diunduh pada 30 Desember 2018 pukul 19.50 WIB

Inilah jadwal lengkap \#JuruBicara Stand-Up Comedy World Tour. 24 kota di 5 benua. (2016). Dalam https://twitter.com/pandji. Diunduh pada 30 Desember 2018 pukul 20.20 WIB

Jadwal lengkap Mesakke Bangsaku World Tour. (2014). Dalam https://twitter.com/pandji. Diunduh pada 30 Desember 2018 pukul 20.05 WIB

JuruBicaraJKT. (2016). Dalam https://pandji.com/jurubicarajkt.Diunduh pada 30 Desember 2018 pukul 20.25 WIB

Melongok Artis yang Kembali "Nyaleg". (2013). https://nasional.kompas.com. Diunduh pada 30 Oktober 2018 pukul 19.25 WIB 
Mesakke Bangsaku World Tour : London \#spon. (2014). Dalamhttp://pandji.com/ mesakkebangsaku-world-tour-london-spon. Diunduh pada 30 Desember2018 pukul 20.00 WIB

Pandji Pragiwaksono Kembali Melakukan Stand Up World Tour.(2018).Dalam https://foto.kompas.com. Diunduh pada 29 Oktoberpukul 19.35 WIB

Part 1 | Caleg Artis Jadi Kosmetik di Parlemen? | WARUNGOPINI. (2018).

Dalam https://www.youtube.com/watch? $v=h 2 c V D 2 P j 0 z g$ . Diakses pada 30 Desember 2018 pukul 20.55 WIB

\section{Peter Drucker on Sales}

andMarketing.(2013).Dalamhttps://www.processe xcellencenetwork.com. Diunduh pada 29 Oktober 2018 pukul $22.20 \mathrm{WIB}$

Pragiwaksono World Tour. (2018). https://www.pilihpandji.com. Diunduh pada19 Oktober 2018 pukul 23.45 WIB

Red clay brick on sale for up to $\$ 1,000$ on eBay. (2016). https://www.theguardian.com. Diunduh pada 30 Oktober 2018 pada pukul 21.50 WIB

Skate brand Supreme sells clay bricks for \$30, internet takes the bait.(2016). https://www.adventuresportsnetwork.com.

Diunduh pada 30 Oktober 2018 pukul 20.35 WIB 